\title{
Physico-Chemical Properties of Biodiesel Produced from Neem oil
}

\author{
Prithviraj Bhandare*, G. R. Naik \\ Department of Biotechnology, Gulbarga University, Gulbarga - 585106, Karnataka, India \\ *E-mail address: prithvi.e87@gmail.com
}

\begin{abstract}
Biodiesel is becoming prominent among the alternatives to conventional petro-diesel due to economic, environmental and social factors. The quality of biodiesel is influenced by the nature of feedstock and the production processes employed. High amounts of free fatty acids (FFA) in the feedstock are known to be detrimental to the quality of biodiesel. In addition, oils with compounds containing hydroxyl groups possess high viscosity due to hydrogen bonding. American Standards and Testing Materials, (ASTM D 6751) recommends FFA content of not more than $0.5 \%$ in biodiesel and a viscosity of less than $6 \mathrm{~mm}^{2} / \mathrm{s}$. In this experiment the seed oils of 30 Neem (Azadirachta indica. A. juss) biotypes were screened and evaluated for their physico-chemical parameters for their potential in biodiesel. The properties of Neem biodiesel were compared with Bureau of Indian Standards (BIS) and the fuel properties of diesel. Results showed that high amounts of FFA in oils produced low quality biodiesel while neutralized oils with low amounts of FFA produced high quality biodiesel. The quality of biodiesel from jatropha and castor oils was improved greatly by neutralising the crude oils.
\end{abstract}

Keywords: Azadirachta indica, biodiesel; physio-chemical parameters; transestrification

\section{INTRODUCTION}

The tremendous increases in number of automobiles in recent years have resulted in greater demand of petroleum products. The depletion of crude oil reserves are estimated for few decades, therefore, effort are on way to research now alternatives to diesel (K. Anbumani and Ajit Pal Singh: 2010). Due to increasing price of petroleum product and environment concern about emission from the car exhaust, the biodiesel has become an area of high concern (Ragit et al., 2011). The biodiesel is an alternative feedstock for depletion of fossil fuel. It has derived from renewable resources such as vegetable oil, which could either be fresh or waste vegetable oil are find useful in Europe, America and Asia as a feedstock in production of biodiesel, as a consequently, biodiesel derived from a wide variety of sources can be used as a direct substitute for petro-diesel fuels (Anya Uzo Anya et al., 2012). They are several non-edible oil seed such as karanja (Pongomia pinnata), jatropha (Jatropha curcas), neem (Azadirachta india) etc. Among these, Azadirachta indica seed which contain 25\%$45 \%$ oil on dry matter basis is non edible oil that can be use in biodiesel production (Anya Uzo Anya et al., 2012). Neem tree is evergreen tree growing in almost every state of India. It is native to Indian subcontinent, South-East Asian countries and it grows all over India. It grows in all kinds of soil and in drier areas (K. Anbumani and Ajit Pal Singh: 2010). 
The physico-chemical properties of fuel are the fuel specifications that define and set the quality standards. For biodiesel, physico-chemical properties are a set of property specifications compared with the Beaureu of Indian Standarda and the fuel properties of diesel. This specification must be met for a fatty acid ester product to carry the designation "biodiesel fuel" or "B100" or for use in blends with any petroleum-derived diesel fuel (Gerpen et al., 2004). The physicochemical properties of neem biodiesel were investigated for its use in diesel engines. The physico-chemical properties that were studied included: specific gravity, viscosity, flash point, fire point, ash content, calorific value, cetane number, acid value, volatility, and saponification value.

\section{MATERIALS AND METHOD}

\subsection{Collection and Characterization of neem seeds}

Thirty different neem biotypes were collected from the different parts of Bidar, Gulbarga, Raichur and Zaheerabad districts (Table 1). Biotypes were screened on the basis of physical appearance and oil-mass solidification. Seeds were inspected and manually cleaned to avoid foreign matter and physical properties such as seed weight, oil content and biodiesel content were determined.

Table 1. Characterisation of morphological and some chemical properties of neem plant.

\begin{tabular}{|c|c|c|c|c|}
\hline Provenance & $\begin{array}{c}\text { No. of tress } \\
\text { studied }\end{array}$ & $\begin{array}{c}\text { Fruit weight of 10 seeds } \\
\text { (gm) }\end{array}$ & $\begin{array}{c}\text { Oil content } \\
\text { (\%) }\end{array}$ & $\begin{array}{c}\text { Biodiesel Content } \\
(\mathbf{\%})\end{array}$ \\
\hline Bidar & 8 & 5.1 & 31.5 & 60 \\
\hline Gulbarga & 5 & 6.8 & 43 & 85 \\
\hline Raichur & 2 & 5.3 & 38 & 65 \\
\hline Zaheerabad & 15 & 7.3 & 40.5 & 78 \\
\hline
\end{tabular}

\subsection{Neem seed preparation for oil extraction}

The cleaned seeds were sun dried in the open, until the casing splits and sheds the seeds. The seeds were further dried in the oven at $60^{\circ} \mathrm{C}$ for $7 \mathrm{hrs}$ to a constant weight in order to reduce its moisture content, which was initially at about 5 to $7 \%$. The separation of the shell from the nibs (cotyledon) was carried out using tray to blow away the cover in order to achieve very high yield. Mortar and pestle were used to crush the seeds into a paste (cake) in order to weaken or rupture the cell walls to release castor fat for extraction (Crentsil Kofi Bempah et al. 2011).

\subsection{Neem oil extraction}

$150 \mathrm{ml}$ of normal hexane was poured into round bottom flask. $20 \mathrm{~g}$ of the sample was placed in the thimble and was inserted in the centre of the extractor. The Soxhlet was heated at $60^{\circ} \mathrm{C}$. When the solvent was boiling, the vapour rises through the vertical tube into the condenser at the top. The liquid condensate drips into the filter paper thimble in the centre, which contains the solid sample to be extracted. The extract seeps through the pores of the 
thimble and fills the siphon tube, where it flows back down into the round bottom flask. This was allowed to continue for 30 minutes. It was then removed from the tube, dried in the oven, cooled in the desiccators and weighed again to determine the amount of oil extracted. Further extraction was carried out at 30 minutes interval until the sample weight at further extraction and previous weight becomes equal. The experiment was repeated for different weights of the sample, 35, 40 and $50 \mathrm{~g}$. The weight of oil extracted was determined for each 30 minutes interval. At the end of the extraction, the resulting mixture (miscella) containing the oil was heated to recover solvent from the oil. Then, the following physicochemical parameters were estimated according to K. C. Verma et al. 2014.

Transesterification: Biodiesel produced by transesterification by alkali process as it results in high purity and yield of the biodiesel product in a short time. Methyl esters of fatty acids were prepared by the procedure described in Singh, Kumar, and Sethi (2006). The yield of methyl esters was calculated using the following formula:

\section{Grams of methyl esters produced \\ Yield of methyl esters $(\%)=-$ X 100 \\ Grams of oil used in reaction}

Specific gravity: specific gravity of the sample is directly proportional to unsaturation and inversely to molecular weight. First, the empty cylinder was weighed, which was further filled with the sample and measured again.

Viscosity: Viscosity is a measure of internal friction. It is an essential property which affects atomization of fuel and mixing of air and fuel in the combustion chamber. Viscosity of oil was measured using Ostwald's viscometer in which the sample was allowed to flow from the etched mark $\mathrm{X}-\mathrm{Y}$ through the capillary of the viscometer. Viscosity was calculated as: $n_{1} / n_{2}=d_{1} t_{1} / d_{2} t_{2}$, where $d_{1}$ is the density of oil, $d_{2}$ the density of water, $t_{1}$ the time of flow for oil, $t_{2}$ the time of flow for water, $n_{1}$ the viscosity of oil, and $n_{2}$ the viscosity of water.

Free fatty acid content: It has a significant effect on the transesterfication of glycerides with alcohol using catalyst. For determining free fatty acid (FFA) content, $25 \mathrm{~mL}$ of methanol was added to $1.5 \mathrm{~g}$ of each oil sample contained in the flask; the mixture was brought to boil in a water bath and then cooled. Two drops of phenolphthalein was added to the solution. 0.1 $\mathrm{N} \mathrm{NaOH}$ was used to titrate the mixture with shaking for proper mixing.

\section{$\% \mathrm{FFA}=\mathrm{V} \times 0.0282 \times 100 /$ weight of sample}

Flash and fire point: Flash point is related to the safety requirement in the handling and storage of fuel; however, biodiesel falls under non-hazardous category. Flash point is the minimum temperature at which the oil vaporises, which when mixed with air forms an ignitable mixture and gives a momentary flash on application of a small pilot flame. The flash and fire points of the test fuels were measured using Pensky Martens apparatus. The sample was filled in the test cup up to the specified level and heated at a slow and constant rate of stirring for proper and uniform heating. The temperature was measured with the help of a thermometer of -10 to $400^{\circ} \mathrm{C}$. At every $1{ }^{\circ} \mathrm{C}$ temperature rise, the flame was directed into the cup through the opening provided at the top cover. The temperature at which flash was observed in the form of sound was recorded as the flash point of that sample. An extension of flash point is fire point, reflecting the condition at which vapour burns continuously for at least for $5 \mathrm{~s}$. 
Ash content: When organic compounds are decomposed at high temperature (500$600^{\circ} \mathrm{C}$ ), the leftover residue is called ash. Ash content includes oxides and salts containing anions suchas $\mathrm{Cl}^{-}, \mathrm{SO}_{4}^{2}$ and other halides and cations such as $\mathrm{Na}^{+}, \mathrm{K}^{+}$, etc. For determining ash content, an electric muffle furnace was used. Five grams of oil sample was taken and placed in a dried and pre-weighed silver crucible. It was placed in the muffle furnace which resulted in burning away the polymer in an air atmosphere at a temperature of $500^{\circ} \mathrm{C}$ for $2 \mathrm{~h}$ and the crucible was weighed after it had been cooled to room temperature. The content was obtained using the equation given below:

$$
\mathrm{As}=\frac{\mathrm{W}_{\mathrm{a}}}{\mathrm{W}_{\mathrm{s}}} \times 100
$$

whereAsis the ash content (\%), Wathe weight of ash (g) andWsthe weight of the sample (g).

Copper Strip Corrosion: A qualitative method of determining the corrosivity of a petroleum product by observing it effect on a strip of polished copper suspended or placed in the product which is known as copper strip test. Copper strip corrosion test was conducted by copper strip corrosion tester (Model No: K25330, Koehler instrument company, inc). ASTM D 130 standard has followed for analyzing the samples. The maximum temperature limit $190^{\circ} \mathrm{C}$ can be applied. A heater maximum range is $0-750 \mathrm{~W}$.

\section{RESULT AND DISCUSSION}

The physical properties such as 10 -seed weight, oil content and biodiesel content of seeds collected from 30 different biotypes from four districts were studied (Table 1). The maximum 10-seed weight was found in seeds collected from Zaheerabad ( $7.3 \mathrm{gm})$. The oil content varied between 25 and 45\%. The maximum oil content was observed in seeds from Gulbarga (43\%) and minimum was found in seeds from Bidar (31.5\%) (Table 1). Higher oil content of neem indicates its suitability as a non-edible vegetable oil feedstock in oleochemical industries (biodiesel, fatty acids, soap, fatty nitrogenous derivatives, surfactants and detergents, etc.). Soil conditions play a significant role in causing variations in oil yield (Srivastava 1999). Again variation in oil yield may be due to the differences in biotype of plant, cultivation climate, ripening stage and the harvesting time of the seeds (Nzikou et al. 2009). To make biodiesel from neem oil, the base-catalysed transesterification was selected as the process and methyl esters were obtained in the range of $60-85 \%$. Gulbarga seeds were found to have maximum biodiesel content $(85 \%)$ and minimum was obtained in seeds from Bidar (60\%) (Table 1).

Density of neem biodiesel ranged from 0.87 to $0.89 \mathrm{~g} / \mathrm{cm}^{3}$. Oil extracted from seeds of Zaheerabad was found to have highest density $\left(0.89 \mathrm{~g} / \mathrm{cm}^{3}\right)$, whereas that from Raichur had lowest density $\left(0.86 \mathrm{~g} / \mathrm{cm}^{3}\right)$ (Table 2$)$. The density of neem oil was found to be higher than diesel. Higher density means more mass of fuel per unit volume for vegetable compared to diesel oil. The higher mass of fuel would give higher energy available for work output per unit volume.

Viscosity of oil obtained was in the range of $5.20-6.50 \mathrm{~mm}^{3} / \mathrm{sat} 30^{\circ} \mathrm{C}$. It was found to be maximum in Bidar seeds $\left(6.50 \mathrm{~mm}^{3} / \mathrm{s}\right)$ and minimum in Gulbarga seeds $\left(5.20 \mathrm{~mm}^{3} / \mathrm{s}\right)($ Table 2). Higher viscosity of biodiesel as fossil diesel implies that biodiesel has a lubricating effect 
in engines which will be an added advantage to the users, since it will reduce wear and tear in the engine.

The flash point and fire point of neem biodiesel were in the range of $125-220^{\circ} \mathrm{C}$ and $155-260^{\circ} \mathrm{C}$, respectively. It was found that oil from seeds from Bidar had maximum flash $\left(165^{\circ} \mathrm{C}\right)$ and fire points $\left(182^{\circ} \mathrm{C}\right)$. They were observed to be minimum in oil from Gulbarga seeds (flash point $150^{\circ} \mathrm{C}$ and fire point $158^{\circ} \mathrm{C}$ ) (Table 2). The ash content of neem biodiesel ranged from 0.01 to $0.028 \%$. Zaheerabad bioidiesel was found to have maximum ash content $(0.028 \%)$ and Gulbarga bioidiesel had minimum (0.01) (Table 2).

FFA was found to be maximum in case of Raichur (1.136\%) and minimum in Gulbarga $(0.524 \%)$ (Table 2$)$. The high FFA content $(>2 \% \mathrm{w} / \mathrm{w})$ favours soap formation and the separation of products will be exceedingly difficult and, as a result, it has low yield of the biodiesel product (Crabbe et al. 2001). The result observed for the Copper Strip corrosion test is that the strip is free from the corrsoion that confirms that biodiesel is free from acids.

The characteristic fuel properties such as relative density, viscosity, flash and fire points of neem biodiesel were studied and compared with the Bureau of Indian Standards (BIS) and the fuel properties of diesel (Table 2) and illustrated in figures 1 to 5.

Table 2. The Physico chemical properties of Neem biodiesel.

\begin{tabular}{|c|c|c|c|c|c|c|}
\hline \multirow{2}{*}{ Parameters } & \multicolumn{4}{|c|}{ Neem biodiesel } & \multirow{2}{*}{ BIS standards } & \multirow{2}{*}{ Diesel } \\
\hline & Bidar & Gulbarga & Raichur & zaheerabad & & \\
\hline Density (gm/ml) & 0.88 & 0.87 & 0.86 & 0.89 & $0.87-0.90$ & 0.839 \\
\hline Viscosity (cST) & 6.50 & 5.20 & 5.50 & 5.90 & $2.5-6.0$ & 3.12 \\
\hline Flash point $\left({ }^{\circ} \mathrm{C}\right)$ & 165 & 150 & 158 & 160 & $>120$ & 54.3 \\
\hline Fire point $\left({ }^{\circ} \mathrm{C}\right)$ & 182 & 158 & 165 & 180 & $>120$ & 59.4 \\
\hline Ash content $(\%)$ & 0.016 & 0.01 & 0.025 & 0.028 & $<0.02$ & 0.0080 \\
\hline Free fatty acid content & 1.128 & 0.524 & 1.136 & 0.564 & -- & -- \\
\hline
\end{tabular}

\section{Specific gravity}

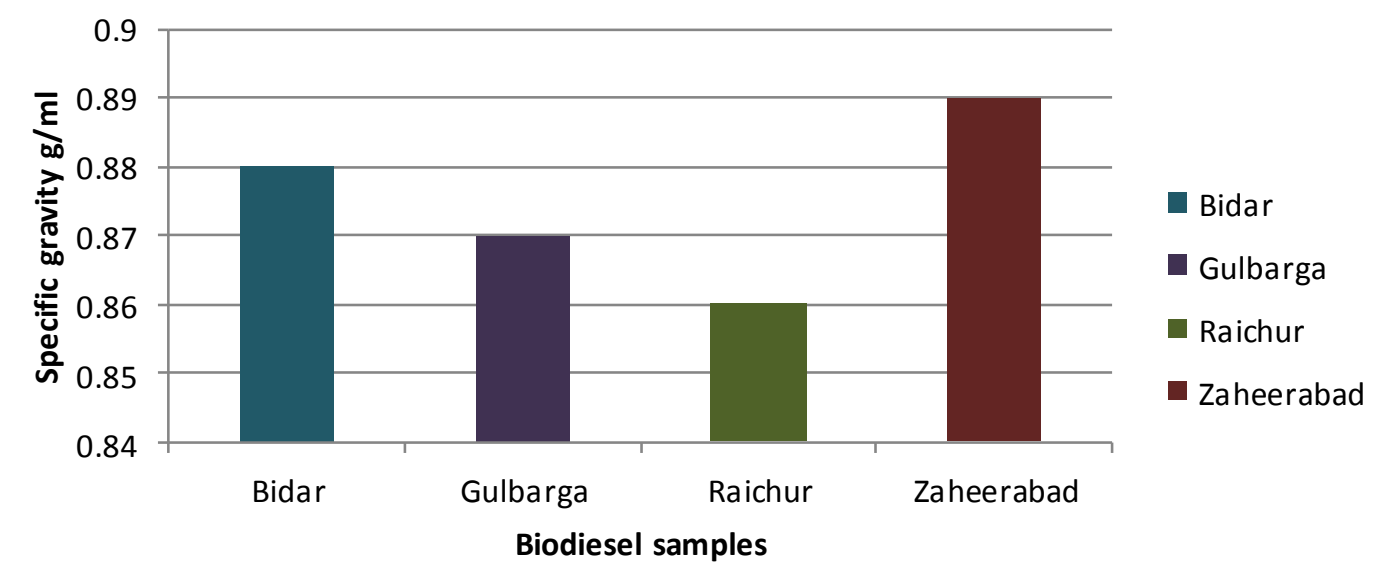

Figure 1. Specific gravity of biodiesel. 


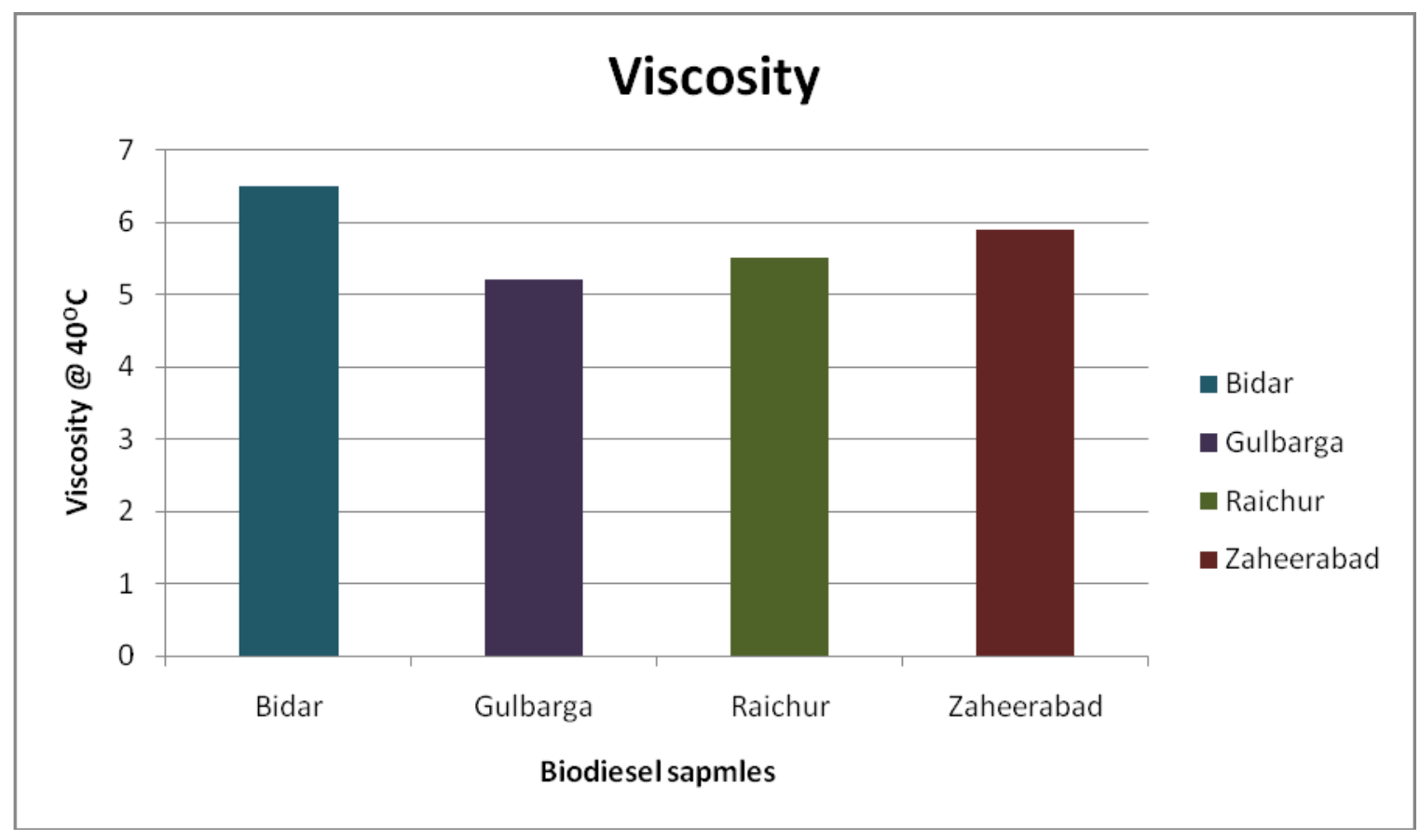

Figure 2. Viscosity of biodiesel.

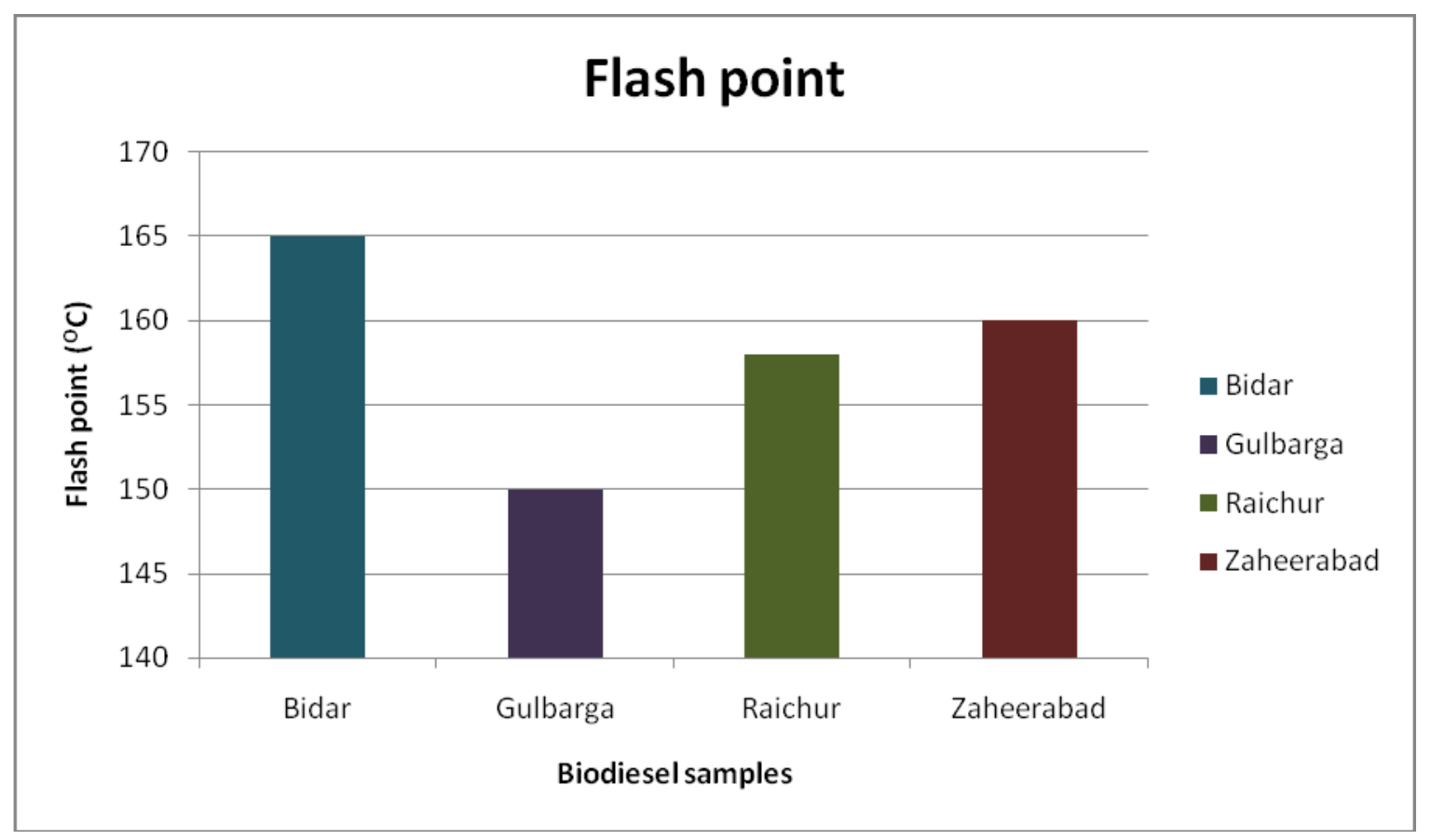

Figure 3. Flash point of biodiesel. 


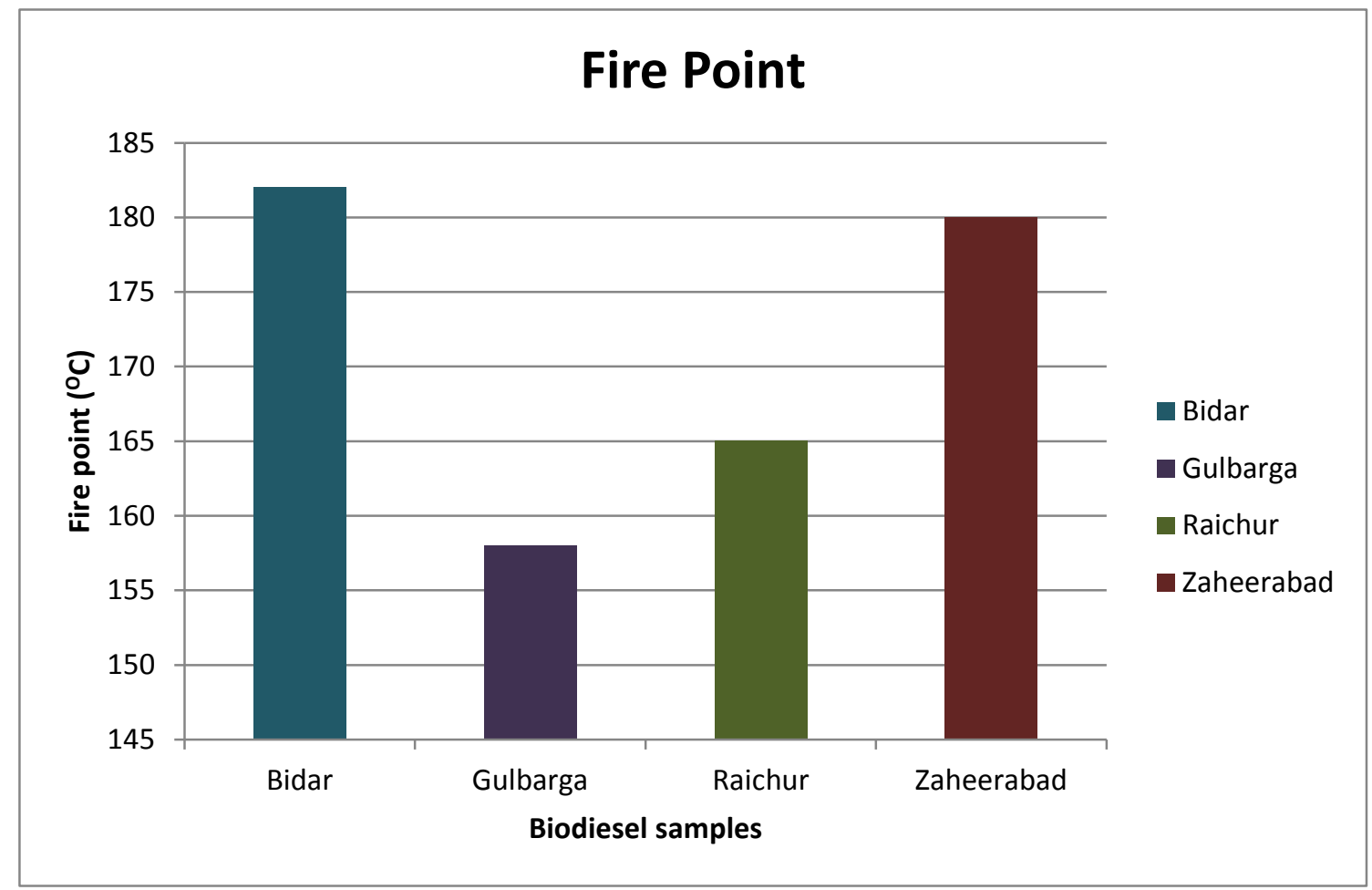

Figure 4. Fire point of biodiesel.

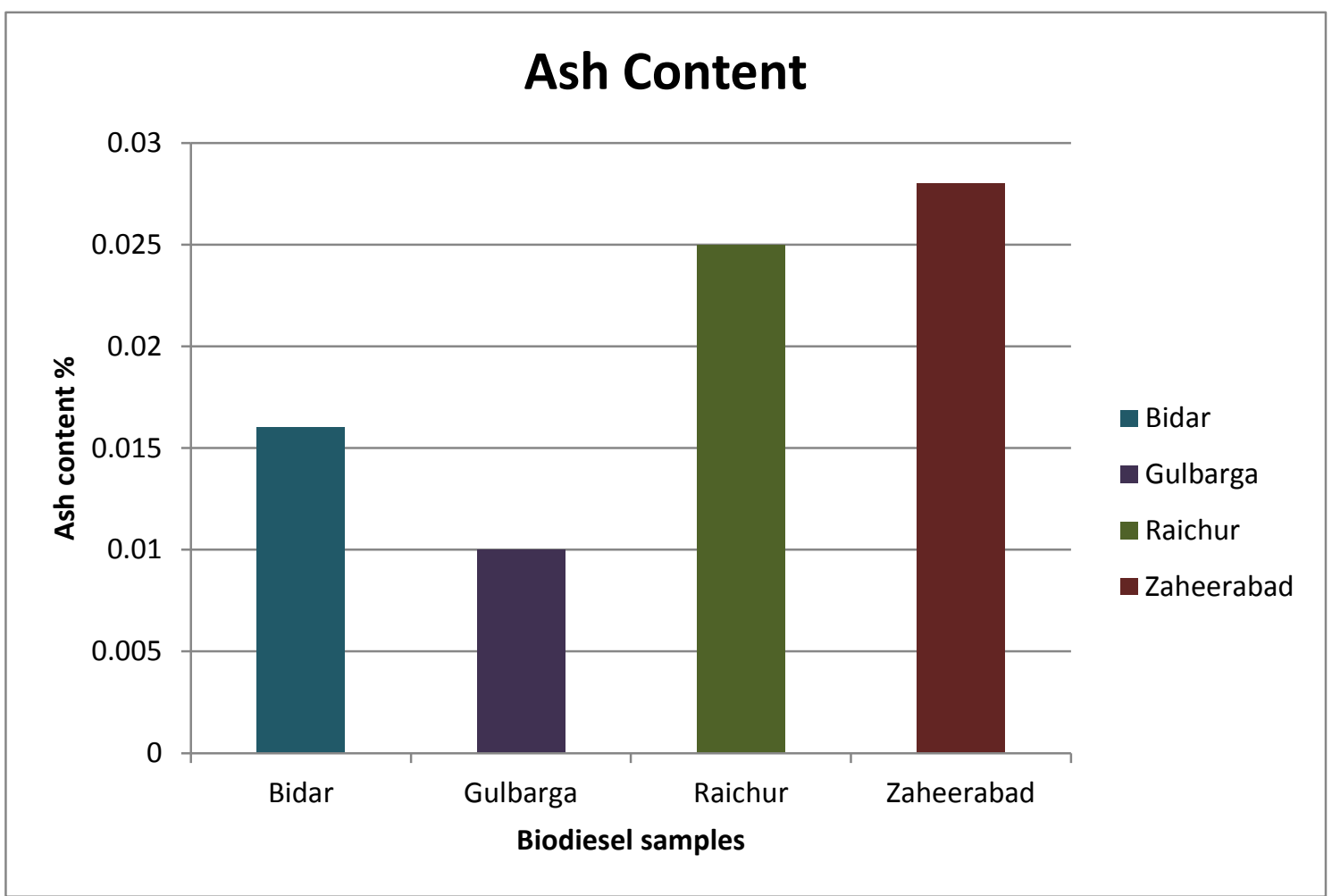

Figure 5. Ash content of biodiesel. 


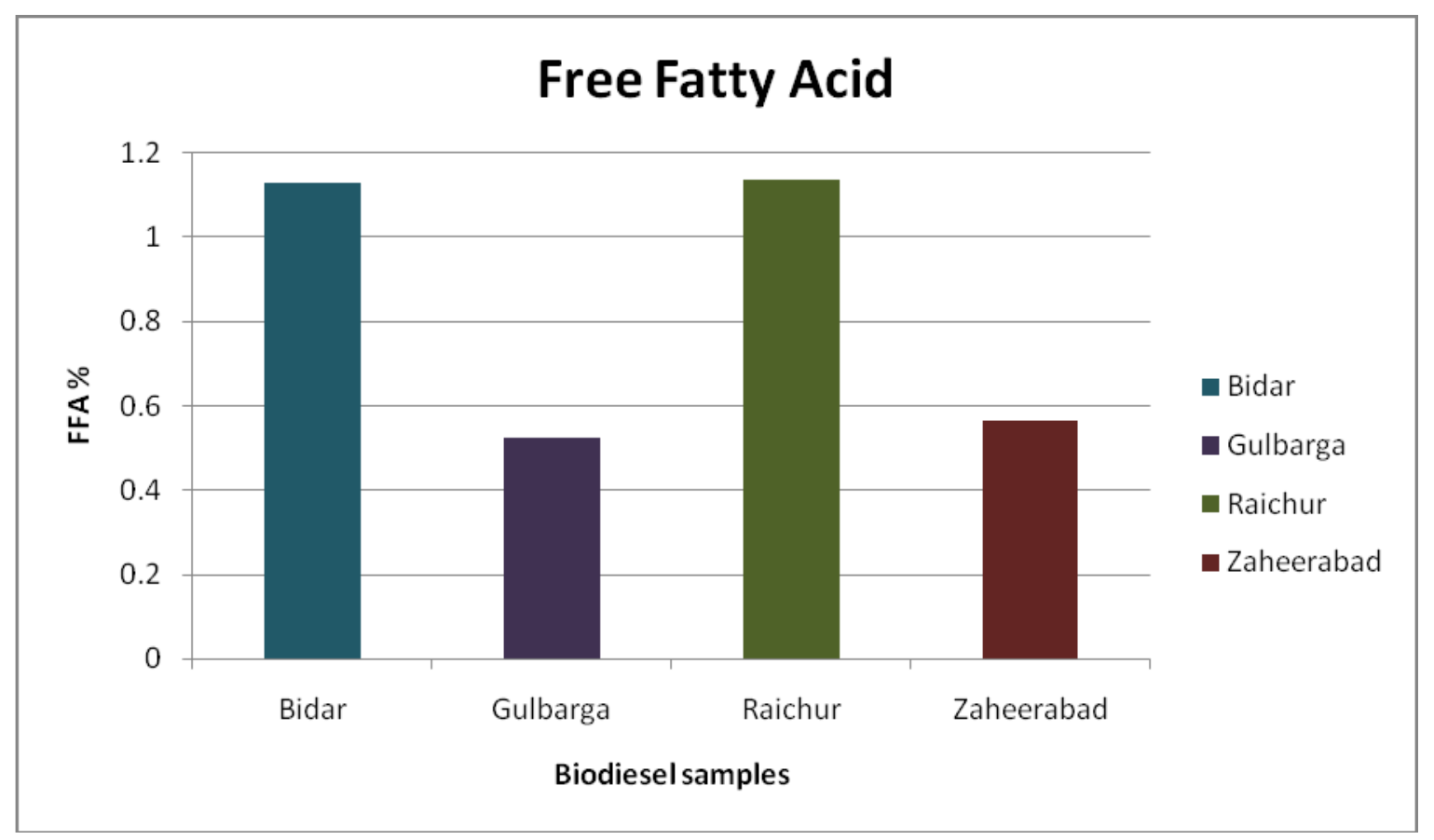

Figure 6. Free Fatty Acid content of biodiesel.

\section{CONCLUSION}

On the basis of the results obtained from all the experiments it was concluded that seeds from Gulbarga district were of better quality with respect to level of oil content, Viscosity, flash point, fire point and ash content. The comparison of characteristic fuel properties of biodiesel of neem with the BIS standard and diesel indicates that the produced fuels are comparable with diesel. Based on the comparative study the neem biodiesel has the potential to become an another source for the biodiesel feedstock and its full potential should ne exploited.

\section{References}

[1] Anya Uzo Anya, Nwobia Noelle Chioma, and Ofoegbu Obinna, Journal of Basic and Applied Chemistry, 2(4) (2012) 21-28.

[2] Crabbe E C N, Nolasco-Hipolito G, Kobayashi K Sonomoto and A Ishizaki, Process Biochemistry, 37 (1) (2001) 65-71.

[3] Crentsil Kofi Bempah, Archibold Buah-Kwofie and Jacob Asomaning, Elixir Appl. Botany, 39 (2011) 4951-4953.

[4] Garpen J. V, Shanks B, Pruszko R, Clements D and Knothe G, National Renewable Energy Laborotory Press, Cole Boulevard, Golden, Colorado, USA, (2004) 1-27.

[5] K C Verma and Nisha Juneja, International Journal of Sustainable Energy, 33 (4) (2014) 946-953.

[6] K. Anbumani and Ajit Pal Singh, ARPN Journal of Engineering and Applied Sciences, 5(4) (2010) 1819-6608. 
[7] Nzikou J M, L Matos, F Mbemba, C B Ndangui, N P G Pambou-Tobi, A Kimbonguila, T Silou, M Linder and S Desobry, Research Journal of Applied Sciences, Engineering and Technology, 1(3) (2009) 154-159.

[8] Ragit S S, Mohapatra S K, Kundu K, Gill P, Biomass Bioenergy, 35 (3) (2011)1138-1144.

[9] Singh P K, A K Kumar and S Sethi, http://dspace.nitrkl.ac.in/dspac. (2006).

[10]Srivastava R, Forest Research Institute (Deemed University), Dehradun (1999). 